\title{
Social development axiological fundamentals in the information age
}

\author{
Liliya Honyukova ${ }^{1 *}$, Hanna Kleshnya ${ }^{1}$, Serhii Ordenov ${ }^{2}$, Ivan Skyba $^{2}$ \\ ${ }^{1}$ National Academy of Public Administration Under the President of Ukraine, 03057, Ezhena Pottier \\ st., 20, Kyiv, Ukraine \\ ${ }^{2}$ National Aviation University, Department of Philosophy, 03058, Kosmonavta Komarova ave. 1, \\ Kyiv, Ukraine
}

\begin{abstract}
The article attempts to reflect correlation of the traditional values and axiological foundations of the information society. The purpose of the article is to present the values being formed during the social development in the Information Age. Particular attention is paid to understanding the modern society moral state, the analysis of information societies value systems, the identification of the managed information field influence on the moral axiological foundations transformation. It is noted that increasing influence of information space on consciousness correlates with the growth of conflict situations in society. Sociocultural and comparative methodological approaches in their dialectical unity have been used to reveal the content of traditional cultural values and values of the information society.
\end{abstract}

\section{Introduction}

Since the second half of the twentieth century, the dynamics of socio-cultural development of mankind is largely determined by the active growth of the information role, both in the sense of communication technologies and content saturation. Overcoming universalistic concepts of the unified human progress of public opinion of the 19th - early 20th century actualizes the problem of conceptual foundations updating of the information age social development. Moral norms, principles, ideals, notions of good and evil, justice, happiness are valuable components of the spiritual culture and moral consciousness of any society.

The basis of the information society is knowledge, information, intellectual technologies and a new way of organizing the technological sphere, which is characterized by rendering and storage of the information in digital format (digitalization). With an extensive system of information resources that are becoming a dominant part of the global economy, the most effective way is network communication. These mentioned information age features significantly influence the socio-cultural environment transformation, which requires philosophical reflection.

For the modern world the basic interpersonal communication practice become forms, that are not associated with direct personal contacts, that updates the following issues in the

\footnotetext{
Corresponding author: gonyukova@ukr.net
} 
field of information culture as personalization and individualization [1]. A number of researchers have paid attention to these problems, among them: H. Arendt, Z. Bauman, U. Beck, M. Castells, S. Kara-Murza, N. Luman, O. Panarin, A. Toffler, E. Fromm and others.

The transition to the digital mode of information transmission results in the network culture functioning as dominant, the gradual decline of the intellectual, meaningful book culture and, directly, spoken word. Changes in socio-cultural reality are evidenced by the emergence of new activities, done only online. Modern communication forms a new language and a special media-linguistic environment, as noted in particular by O. Antipova [2]. The growing development of the information sphere creates the preconditions for significant socio-economic, political and cultural changes in the society life. Information is transformed from an instrument of communication into a goal in itself, ordering behaviors, inclinations of people and their interests, influencing the transformation of speeking culture [3]. The standards of culture and its values are being changed: morality and ethics lose the place of interpersonal relationships cultural imperative.

The essence and problems of values origin, their classification and systematization were investigated by S. Avaliani, V. Andrushchenko, I. Bychko, N. Bondarenko, V. Blumkin, V. Vasilenko, V. Hnatenko, H. Zaichenko, M. Kahan, V. Kozakov， P. Kravchenko, I. Nadolnyj, O. Ruchka, P. Pronyakin, V. Tugarinov, V. Shinkaruk and others. At the same time, we have not identified definition and systematization of the axiological foundations of the information age in the scientific literature, that actualizes this research.

\section{Purpose of the article}

The purpose of the article is to present the information society values in the socio-cultural development of the information age. The purpose of the article stipulates the following objectives: analysis of the value attitudes of the information society; identification of the communication features and its influence on the axiological foundations transformation of social development.

\section{Research methodology}

The formulated purpose and objectives of the study determine the use of appropriate scientific and methodological tools. In particular, sociocultural and comparative methodological approaches in their dialectical unity have been used to reveal the content of traditional cultural values and values of the information society, as well as to compare them. In addition, general research methods and principles were used in the research process: ascent from abstract to concrete; conformity and relativity; analysis and synthesis; generalization; deduction; induction and others. The theoretical basis of the study were the works of both recognized classical and contemporary researchers: L. Drotyanko; Z. Baumann, W. Beck, M. Castells, S. Kara-Murza, N. Luman, O. Panarina, G. Pocheptsov; A. Toffler, E. Fromm and others.

\section{The results}

The profound structural and functional changes of a society, connected with its information assertion, are spreading in the global space and affect all spheres of life of the modern person. In the philosophical and methodological dimension, the information space is understood as the environment of information dissemination in the society influenced by cultural, economic, political, technological and other factors. But all of these factors are the 
product of the result of the social activities, and therefore, interdependent and independent themselves.

The specificity of the sociocultural approach to the information space lies in the revealed interconnection of the media with the broadcasting of cultural models, that determine the social identity of individuals. The interaction and even the confrontation of the models of self-identification in the information space, in turn, leads to a sharp increase in the information content volume with predefined meanings, the purpose of which is to influence the consciousness. Thus, the information space is not only a collection of diverse data accumulated by mankind, it also serves as a enviroment of manipulation with the mass consciousness [4], which was eventually reflected in the works of both foreign and domestic researchers, in particular: L. Drotyanko; G. Pocheptsova; T. Pody; S. Topalov and many others.

The formation of a new person - the "information person" - is one of the basic characteristics of the information age society. This social unit is being distinguished by a certain outlook, which is formed as a complex of acquired values: traditional (formed in the family circle), personal (defined by the experience) and social, which are the result of the social environment influence. However, all of these components of the modern worldview are in one way or another borrowed from the virtualized world of the information age.

In the context of the informatization deployment, each of the dialectically interconnected principles of a person - physical, mental and social - requires special consideration, since only in this case the new possibilities of the information society can be fully used for human development. Without taking into account the specifics of these principles, informatization can cause negative social consequences [5]. The deterioration of the cultural and educational level of the young generation, the increase in the number of psychological problems and mental disorders leading to deviant behavior of children, adolescents and youth is of particular concern to the authors [6]. At the same time, people in the information society are influenced by the processes of informatization and are changing under the pressure of new information technologies and communication channels. Modern technologies, included in the environment of social relations, are an important factor in social transformation, and their impact on human quite often has a very negative character. As S. Drozhzhina and I. Kobzar rightly point out, modern information technology can change or even destroy the value priorities and the life world of person as a whole, distracting from the realities of life, immersing in virtual reality. So in the conditions of information society, emerges a new way of existence of culture - in virtual reality [7]. Today, virtual reality objectively exists in parallel with the ordinary life of any person. This phenomenon, inherent for the information age, affects the mental development of a person, his relationship in society, in general, the development of society, so this issue needs considerable attention. But scientists warn us, pointing out that one can plunge into unreality by breaking mentally away from the real world.

As a result being in the virtual world of conflicting information flows, a person is released from personal identification markers, such as citizenship, nationality, gender, age, and other factors of self-identification. At this stage of the society's functioning, the relative independence of the individual's desires (of course, committed to new modified values) from the previous cultural tradition is being achieved. In this regard the question arises: how deep have these changes come into the life of a information age person? In response, it seems appropriate to consider firstly the Information Age Person in order to find out, which value environment he embodies.

In modern conditions, the complexity of moral and valuable identification is determined by the formation of a specific information consciousness of the global world, which changes the traditional moral values, as well as the contradiction of the current situation: on the one hand, the information society requires a person to open his creative potential, 
freedom of self-recognition, behavior way, traditions, values, etc., on the other accessibility and volume of information causes a certain virtuality of freedom, invoking internal personal value conflicts.

Increasing interest in the problem of studying and analyzing values always appears in times of spiritual crises, the fractured value system, the search for new cultural foundations of society and orientations of human existence. Equally important in the context of cultural globalization is the comprehension of what the spiritual essence of traditional culture is, its axiological basis, because the system of spiritual, in particular moral, values plays a significant role in the adaptation of the individual. And in the conditions of socio-cultural society transformation it guides, promotes or impedes the further development of society [8]. Moral values serve to integrate society, help individuals make socially acceptable choices about their behavior in important situations.

Without a clear scientific understanding of the essence and specific features, the place and role of axiological foundations, the definition of the value-forming core of society, it is impossible to predict further social development. Defining the spiritual foundations of life and focusing on the traditional culture values played a consolidating role in ensuring understanding in society, fulfilling the function of forming the consciousness of the people and preserving the original national culture. The preservation of these values is especially relevant in the information age. Only by grasping the value foundations of one's own culture and creating the conditions for their realization one can find own path of development. However, the information age, as a fertile postmodern culture environment, poses serious challenges to society in the form of simulacrumization, deconstruction, and, finally, interpretation of historical facts. As a result, we are forced to recognize, in the words of J. Baudrillard, a reflection of what does not really exist [9], as a true reflection of not only the past but also the present.

As a result, the future is presented as deconstruction, that is, in the form of a modified concept through which the reality was understood until the moment of deconstruction. As an example we can see the ideology of the commonwealth of socialist republics in the Soviet Union, which has been changed by the ideological and value concept of the nonaligned status of independent states. However, it was first transformed for the benefit of the CIS and subsequently for EU and NATO integration. In this regard, the analysis of previous realities is carried out from the standpoint of "here and now", without deep analysis of conditions, processes, and, most importantly, consequences. Causation is being broken down. As a result, there is a state of uncertainty, when all the sensory-forming frameworks that held the present reality are released, and are merely an expectation of the present, not even the future, without critical reflection on historical experience.

Let us return to the higher values - public ones. The modern period is characterized by the de-ideologization of society, rethinking and changing the value system, and is defined by scientists as an "axiological revolution". Socio-economic reforms, rapid pace of life, economic crisis, transition to a market economy have destroyed the "old" values and actualized the "new" ones. These factors constitute one of the reasons for person alienation from moral values, norms and meanings, which has become the subject of scientific debate in recent decades and is referred to as "cultural degradation" (Y. Lotman). We observe the legitimation processes of the virtual social pseudo-memory creation, which fundamentally changes the value-moral principles of society. Note that both the new virtual values and the new virtual history, for the most part constructed not just by an individual, because in the world of ready-made clichés, creativity, as an act of creating a new one, becomes a process of compilation of simulacra.

Ukrainian single information and communication space has become a part of the global information space, acquiring both positive and negative features inherent to the global information society. Throughout the world, the negative effects of human trapping on the 
role of information are deepening, which accordingly strengthens the value orientations of both individuals and communities. It seemed that endless opportunities for self expression led to the creation of new small groups that shared certain interests and, accordingly, certain value foundations. Against this background, there is a change in the nature of interpersonal relationships, which, in our view, is fully consistent with the concept of shifting paradigm of M. Maffesoli, who states that "individualism is not a universal value neither in time nor in space, we can assume, that the principle of individualization is increasingly more denied in the heart of Western civilization" [10]. So the world is being changed. And indisputable ten years ago the values of individualism are being called into question. The Western, "only true" axiological paradigm is being changed rapidly, but we haven't realized it yet. Open information spaces make it possible to be part of the whole, or at least to be informed about the change in the world value "mainstream".

In the realm of social development globally there is the same radical construction of virtual reality. When Europe had already changed the vector from autonomy, individualization and cosmopolitan slogans of "EU citizen" to socialization within small, including national groups, we were only trying to master the individualization of the Western model. But have we become part of the system of values traditionally called European? Moreover, do we fully realize it? And are we ready to accept unambiguously the changes being produced in the global world by the major players, if we fully understand neither the essence of what is changing nor the consequences of these changes?

The famous Canadian philosopher Charles Taylor [11] called these changes "diseases of our time." Among them - individualism, which is characterized by a narrowing of the social vision, the focus of the individual on his private life, rationalism, pragmatism. The public consciousness of citizens is increasingly manifested through such phenomena as social apathy, amorphous social interests, diminished educational and cultural needs, liberalization and popularization of immoral manifestations, etc.

Rethinking values and priorities, the emergence of new ones that respond to the needs of today and are adapted to common values and withstand critical thinking - a complex, long-lasting, and most importantly, objective and irreversible process, that has never been completed as quickly as in the modern world. Humanity of the XXI century. living with the illusion of a radical replacement of traditional values with new ones. But in the transitional periods of its existence, the society generates not only innovative ideas, but also returns to the primordial forms of socio-cultural existence. This process, which J. Huizinga called "barbarization," is referred by modern scholars as archaisation [13]. Archaicization is described as the result of the passage of a subject of cultural programs, that have historically evolved in layers of culture and have formed in simpler conditions. They do not meet the growing complexity of the world, the nature and scale of the dangers. Archonization is only a form of regression in which the activity program is inherent in the public society, associated with the Taoist culture and the domination of purely local worlds, in which the relations are based on the emotions of people whose worldview is limited to personally known members of the local community, not knew development as a cultural asset.

The system of the information age values is characterized by such features as the transformation of the traditional values status: the collectivist principles are weakened; creativity is replaced by creativity (or the ability to compile); cosmopolitanism is supplemented by local patriotism (or, in other words, urbanism); civil patriotism is replaced by national patriotism; the meaningful content of individual values is transformed, for example, freedom as autonomy of personality is transformed into freedom of choice and declaration of moral values; autonomous personality with established moral convictions, replaced by a subject with flexible morals; priorities in the value system drift to consumer, 
utilitarian; leading place is posttolerance as the sole factor of multimorality. A separate "value" of the information age personality is its involvement in the virtual world.

Table 1. The transformation of the axiological foundations of the information age.

\begin{tabular}{|l|l|}
\hline Traditional axiology & Information age axiology \\
\hline communitarianism & individualism \\
\hline ethics, morality & aesthetics of forms \\
\hline $\begin{array}{l}\text { autonomous personality, with established } \\
\text { moral convictions }\end{array}$ & declaring moral values, flexible morals \\
\hline altruism & egoism \\
\hline tolerance & posttolerance \\
\hline creativity & compilation \\
\hline integrity & fragmentation \\
\hline realism & virtualization of reality \\
\hline human and sociocentrism & technocentrism \\
\hline
\end{tabular}

Historical experience demonstrates a permanent process of abandoning traditional values and returning to them again, not as a rethinking, but as a creation of new ones. Pluralism of values does not compensate for the lack of a stable system of relationships, that would contribute to the growth of people's spiritual potential, but merely testifies to the search process, the critical point of the state of "denial negation". Therefore, the "absolute" and fundamental values- life, health, truth, beauty, good, family, work, well-being, wellbeing of children, etc., become irrelevant, despite their ambivalence. At the level of society, social group, individual, they act as the "architect" of the sociocultural space, since they are objective in nature, though they are subjective in their essence.

The value "deficit" of Ukrainian society is a reflection of the global spiritual crisis, which is actively offset by the values defined by the Western mentality: individualism, pragmatism, activism, technicalism, but they do not coincide with the characteristics of the Ukrainian people's own mentality. The Ukrainian society representative must be familiar only with individualism among those named, which has a clear emotional (not rational, as in the Western European version) color.

Admittedly, Ukrainian society continues to be in a state of "blurring" of axiological orientations and lack of firm beliefs about ideals, moral values, as evidenced by numerous polls conducted by the Ukrainian Institute of Sociological Research. Represented values remain underdeveloped, formally stated, they do not become universally accepted, leading to a split of society.

Social consciousness is based on two types of value systems: innovative, modern (human personality, dignity, self-realization, certain hedonism, etc.) and traditional (conservatism, family values, etc.). And the latter, according to the researchers, remains decisive. The absence of a universally recognized system of moral values always causes loss of moral health of people, society, causes disorientation and a certain danger in the sense of spiritual integrity.

The centrifugal trends of the information age reinforced the desire of man to obtain a reliable means of adapting to a "split and cracked" culture, to obtain or keep his identity. A characteristic and objective feature of human development is the change in the value system. Values are constantly arising, spreading, functioning for a certain period of time, dissolving, disappearing, re-emerging etc. So they function in the social structure as ideasvalues of social groups, communities, classes, their political representations. The value system always acts as a set of values of a particular social group as an organized social force. This raises the problem of harmonizing the values of social groups and society as a 
whole. As the historical experience of mankind testifies, sometimes the inconsistency between the values of different social groups leads to revolutions and changes in the place of social groups in social organization, as well as in the revision of the values system and the formation of new, compromising axiological systems.

R. Inglegart links change of value system with change of generations, because within one generation values practically do not change. He rightly points out, that the relationship between the value system and socio-economic status is complex and paradoxical. In today's context, postmaterials usually have a solid job, better education, and higher incomes than materialists. At the same time, the values they are guided by are characterized not so much by compulsory employment and high income as by interesting work and raising social status. However, we have doubts about the universality of this thesis. Especially after the 2008 global economic crisis. Indeed, at the beginning of the new millennium, the economic importance of the social stratum of intellectuals, "white" and "blue collars", which, according to the assumption, should not profess exclusively materialistic values. But practice shows that neither the laws of nature, with the physiological needs of human, nor, moreover, the socio-economic principles have not changed. And they can't be changed for a number of reasons.

A person of information age, or post-industrial one, as well as a person of industrial and pre-industrial age, needs to satisfy own physical needs. Regarding meeting the cultural and social needs, we can give a single answer - an open information space with virtually endless possibilities. But statistics convince us, that the population of the globe is steadily increasing. And according to estimation, the human population in 2017 reached 7.5 billion people. And the resources necessary to provide basic physical needs are limited. Despite all the beliefs in the change of the mankind values, described by Abraham Maslow [14] in 1943, the hierarchical model of human needs remains unchanged: only by satisfying basic needs - physiological and secure - there is a need to meet the needs of socialization and self-determination, creation. In our opinion, it is impossible to change the order of satisfaction of needs, and they directly correlate with the value attitudes of a person. The above example only confirms that basic needs related to material security are fully met in some parts of the population. This actualizes the need for self-realization and raising the social status of the described category.

To the foregoing, we can add, that the middle class is not all the world's population on a global scale. Moreover, this class is becoming smaller. Therefore, it is not possible to build new axiological paradigms on a global scale, based on the results of a survey of specially selected respondents, even among residents of the whole country. The results of the economic crisis have significantly shifted the vector of the needs of the population even in the US, confirming the election of Donald Trump with a fundamentally anti-liberal political agenda, which most likely fits the value concepts of the pre-modern period, in its not the best version.

\section{Discussion}

The sign of the post-modern world is the value crisis, which is caused by active efforts to create a set of "generalized" global human values. The problems of the axiological crisis of modern times were explored by Z. Bauman, K. Bade, and R. Inglhart. The increasing crisis and growth of unpredictable human existence, the feeling of insecurity against uncontrolled global change, stimulates the rejection of strategic goals and objectives, disintegrating private and public life, violating moral and traditional values.

According to Z. Bauman, in today's context, partnership is no longer what should be achieved through the duration of efforts and periodic sacrifices, but is something, that is expected to give true pleasure, which is rejected if it does not live up to those expectations 
and is maintained only until (and no more) as long as it continues to give enjoyment. Under certain conditions, even the smallest obstacle is capable of destroying any partnership, and minor misunderstandings can lead to sharp conflict [15].

In turn, the axiological crisis leads to the loss of socio-cultural identity, which is internally caused by globalization processes. The axiological crisis and the loss of sociocultural identity are absolutely interdependent, commensurate and inseparable processes inherent in the information age. And since they exist in a single socio-cultural space, they cannot be separated individually. At the same time, we can identify as positive consequences of these crises: - in the form of expanding the adaptive capabilities of the "information person"; and negative ones - in the form of escapism, unpromising outlook, inability to determine strategic goals and objectives, focus on current problems of being, loneliness, etc.

So, on the agenda is the strengthening of the axiological component. The search for a way out of the global crisis of personality is carried out in several directions: the construction of a new identity based on universal moral values, cultural universals and the renaissance of traditional cultural values. The existence of fluctuating identity leads to the emergence of a distinctive set of spiritual (in particular, moral) time-tested values: goodness, freedom, sense of life, justice, conscience, mutual respect, human dignity, virtue, humanity, as well as family values. Traditional spiritual social values are a barrier to manipulation and all kinds of imposition about socio-cultural identification, to create socalled global identity and social development in general.

Humanity as a whole has certain spiritual values coincidence, the difference lies in their hierarchy, in setting priorities. Temporal priority of individual values over the spiritual ones; lack of a clear system of values, moral guidance; erosion of morality - all this directly affects the level of conflict in society. The loss of moral imperatives in various spheres of public life - economy, politics, management, etc. - exacerbates the issues of dehumanization, desocialization, complicates the construction of a single model of sociocultural identity of society. And this is the main criterion for life potential and social development, the ability to identify and overcome internal and external challenges, while maintaining their own identity, providing historical perspectives.

\section{Conclusions}

As a result of the study of the traditional cultural values role in the context of the values formation of the information society, it is established, that socio-cultural shifts are taking place in the modern world, which have structural nature. At the same time, these shifts are based on such a traditional human quality as concern for immediate needs or dangers, rather than on things that seem distant or unrelated to them. The intergenerational process of values change leads to the gradual modification of the political and cultural norms of modern post-industrial society. Such a transition from materialistic value priorities to postmaterialistic ones, and on the contrary, brings to the forefront new problems and in many respects serves as an impulse to find lost value foundations. Particular attention needs to be given to understanding moral posttolerance as a state of "out of taboo", that demoralizes modern society in some way. It is worth noting that the "open" information space of modern times is artificially managed, moderated and has a significant influence on the transformation of axiological foundations and cultural values. It is this information space that drives contemporary people to pre-set value judgment, "softly" imposing the only possible solutions according to the mainstream information. Contradictions with the holders of other values and socio-cultural norms, or simply with critically minded individuals who do not wish to uncritically adopt the dominant doctrines of the information society, have a significant impact on the rise of conflict situations in the world. 


\section{References}

1. O. Antipova, Sotsiokulturnyi prostir informatsiinoi ery: vzaiemovplyv pryrodnoi ta shtuchnoi mov [Sociocultural space of the information age: mutual influence of natural and artificial languages]. (2013). Dnipropetrovsk: DDUVS [in Ukrainian].

2. Z. Bauman, Individualizirovannoe obshchestvo [Individualized society]. (V.L. Inozemtseva, Trans, Eds.). (2005). Moscow: Lohos [in Russian].

3. Baudrillard, J. Simulacra and Simulation. Publisher University of Michigan Press. (1994). DOI: 10.3998/mpub.9904

4. S. Drozhzhina, I. Kobzar, Aksiolohichno-ekzystentsiini determinanty informatsiinoho suspilstva [Axiological-existential determinants of the information society]. Hileia, Gilea, 80(1), 190-196, (2014). [in Ukrainian].

5. O. Dzoban, S. Zhdanenko, Sotsiokulturnyi prostir informatsiinoho suspilstva yak seredovyshche buttia suchasnoi liudyny [The socio-cultural space of the information society as a medium of being a modern person]. Visnyk Natsionalnoho universytetu "Yurydychna akademiia Ukrainy imeni Yaroslava Mudroho", Bulletin of the National University "Yaroslav the Wise Law Academy of Ukraine", 2(21), 12-21, (2014). [in Ukrainian].

6. L. Drotianko, Sotsialni transformatsii movlennievoi kultury v informatsiinu eru [Social Transformations of Speech Culture in the Information Age]. Visnyk Natsionalnoho aviatsiinoho universytetu, Proceedings of the National Aviation University, 1(19), 811, (2014). [in Ukrainian]. DOI: 10.18372/2412-2157.19.10020

7. A. Gudmanian, L. Drotianko, S. Sydorenko, O. Zhuravliova, S. Yahodzinskyi, Social transformations of speech culture in information age. E3S Web Conf.Volume 135, 2019 Innovative Technologies in Environmental Science and Education (ITESE-2019). (2019) https://doi.org/10.1051/e3sconf/201913503081

8. S. Krymskyi, Arkhetypy ukrainskoi mentalnosti [Archetypes of Ukrainian mentality]. Problemy teorii mentalnosti, Problems of the mentality theory. Kyiv: Nauk. Dumka [in Ukrainian]. (2006).

9. A. Maslow, Motivation and Personality. Harper \& Row, Publishers, Inc. (1954).

10. M. Maffesoli, Chas plemen. Zanepad indyvidualizmu u postmodernomu suspilstvi [The Time of the Tribes: The Decline of Individualism in post modern society]. (2018). Kyiv: Kyiev.-Mohylian. akad. [in Ukrainian].

11. S. Ordenov, Arkhaizatsiya hlobalizovanoho sotsiumu v informatsiinu dobu [Archiving the globalized society in the information age]. Natsionalnoho aviatsiinoho universytetu, Proceedings of the National Aviation University, 2(28), 54-64, (2018). [in Ukrainian]. DOI:10.18372/2412-2157.28.13373

12. S. Ordenov, H. Kleshnia, Demodernization as a hybrid form of modernization of traditionalist society in the globalized world. Humanities \& Social Sciences Reviews, 7(4), 1241-1247, (2019). https://doi.org/10.18510/hssr.2019.74171

13. T. Poda, Manipuliatsiia yak sposib transformatsii suspilnoi svidomosti [Manipulation as a way of transforming public consciousness]. Visnyk Natsionalnoho aviatsiinoho universytetu, Proceedings of the National Aviation University, 2(20), 47-50. (2016). DOI: $10.18372 / 2412-2157.20 .10395$

14. Ch. Taylor, The ethics of authenticity. Cambridge: Harvard University Press. (1995).

15. S. Topalova, Manipuliuvannia svidomistiu yak tekhnolohiia vprovadzhennia politychnykh mifiv [The manipulation of consciousness as a technology for the 
introduction of political myths]. Visnyk Natsionalnoi yurydychnoi akademii Ukrainy imeni Yaroslava Mudroho, Bulletin of the National Law Academy of Ukraine named after Yaroslav the Wise, 7, 164-171, (2011). [in Ukrainian]. 